\title{
Some Claims Made for Critical Realism in Economics: Two Case Studies
}

by Geoffrey M. Hodgson

10 May 2002

Published in Journal of Economic Methodology, 11(1), March, pp. 53-73.

\author{
The Business School, University of Hertfordshire, Mangrove Road, Hertford, Hertfordshire SG13 8QF, UK \\ Address for correspondence: \\ Malting House, 1 Burton End, West Wickham, Cambridgeshire CB1 6SD, UK \\ Email: g.m.hodgson@herts.ac.uk
}

KEY WORDS: critical realism, Marxism, abstraction, explanation

\begin{abstract}
Instead of examining critical realism directly, this essay critically examines claims made by two prominent critical realists, namely Andrew Collier and Tony Lawson, on behalf of their philosophy. These are (a) that critical realism supports Marx's law of the tendency of the rate of profit to fall, and (b) that critical realism is illustrated by the workplace organisation theory of the relative decline of the British economy. It is argued that the first claim is false and the second is unsubstantiated. Furthermore, propositions that are rejected by Collier and Lawson are shown in fact to be consistent with critical realism. These two case studies raise important questions concerning the claims made for critical realism on behalf of its adherents. Some questions are also posed concerning the character of critical realism as a movement.
\end{abstract}




\title{
Some Claims Made for Critical Realism in Economics: Two Case Studies
}

\author{
Geoffrey M. Hodgson ${ }^{1}$
}

\section{Introduction}

Critical realism has established a substantial following in the last few years, leading to the formation of the International Association for Critical Realism in 1997. ${ }^{2}$ The works of Roy Bhaskar have attracted widespread interest. His ideas have been adopted and applied by leading social scientists, including Margaret Archer, Andrew Collier and Tony Lawson. The core philosophical ideas of critical realism are beginning to be widely debated by economists and other social scientists (Baert, 1996; Faulkner, 2002; Fleetwood, 1998; Lewis, 1996; Runde, 1998; Walters and Young, 1999).

It is not the primary intention of this article to discuss those core ideas. Instead, the foremost aim here is to examine some of the claims made on behalf of critical realism, as guidance in the development of economics as a discipline.

However, there is little consensus among critical realism on key questions of concern for economists. For instance, critical realists are themselves divided on the question of the value of econometrics. On this, compare Paul Downward's (2000) defence of some econometric techniques with Tony Lawson's (1997) rejection of them in all cases where 'open systems' are involved. Other divisions exist. Some 'Analytical Marxist' supporters of critical realism have declared in favour of 'explicit abstract models, sometimes highly formalised as in game theory' and other 'rational choice models' (Wright, 1994, pp, 183-9). But Lawson (1997) and several other critical realists oppose such sentiments.

It is also notable that leading critical realists have made a number of normative and policy assertions. These include: the allegedly 'emancipatory' nature of critical realism (Bhaskar, 1991, 1993); the claim that 'critical realism shows the fallacy of several of the classical arguments against socialism and supports the possibility of a form of socialism' (Bhaskar and Collier, 1998, p. 392); and the insistence that the critical realist perspective leads to a rejection 'of contemporary social democracy' (Bhaskar, 1989, p. 6). Elsewhere I have shown that these claims do not logically follow from critical realism (Hodgson, 1999). 
The present article scrutinises some further claims made for critical realism. These claims are of a theoretical nature and are of interest for economists. Concerning the alleged implications of critical realism for economic theory, here too there is a range of stances. This range is evident when the two 'critical realist' examples chosen here are compared, one taken from the work of Andrew Collier (1989) and the other from the work of Tony Lawson (1997). On the one hand, Collier argues that critical realism directly supports a particular theory Marx's law of the tendency of the rate of profit to fall. On the other hand, Lawson is more circumspect. One chapter of his book is titled 'Illustration'. Here he suggests that the deployment of critical realism is 'illustrated' by the theory that the type of workplace organisation in Britain helped to bring about relative industrial decline. Lawson (1997, p. 247) claims that such a theory seems 'broadly consistent with critical realism'. But Lawson (1997, p. 326) adds a significant qualificatory footnote to the beginning of this 'illustration' chapter:

Substantive explanations, then, even when serving illustrative purposes, ought not be tagged 'critical realist'. Nor, incidentally, should they be interpreted as constituting evidence by which the critical realist explanatory framework is itself to be assessed. ... In short, the examples and discussion which follow merely provide ... an indication that explanatory endeavours consistent with critical realism are feasible in the social realm.

In fact, Lawson explores only one 'illustration' of critical realism. His words provide a welcome qualification concerning the theoretical impact of his methodology. Collier is more definitive; he sees critical realism as positively supporting at least one specific theory. In contrast, Lawson sees the association between theory and critical realism as in a sense negative, in that critical realism is used to reject some theories, leaving a sizeable set of different theories that are compatible with critical realism. A purpose of the present paper is to argue that while Lawson's position is preferable to Collier's, the set of remaining theories is even larger than suggested by Lawson, and critical realism has even less discriminatory power at the theoretical level, than Lawson suggests. This is because at least one of the important rival theories rejected by Lawson is in fact consistent with critical realism.

The 'critical realist explanatory framework', as such, is not assessed in the present essay. Nevertheless, four prominent claims have been made by critical realists: that (a) critical realism supports Marx’s theory of the falling rate of profit (Collier, 1989), and (b) critical realism is 'illustrated' by the workplace organisation theory of the relative decline of the 
British economy (Lawson, 1997). Furthermore, both (c) Collier (1989) and (d) Lawson (1997) reject some alternative theories or explanations, seeing them as inconsistent with critical realism.

Critical realists range between (i) making claims concerning 'implications' or 'illustrations' of critical realism of the above type, and (ii) stressing that no philosophy (critical realism included) can provide detailed or substantial theoretical or policy implications. I believe that philosophy can only be a guide on such matters; it cannot generate theory or policy on its own. Lawson himself seems to take this view, but then in the name of critical realism he rejects some theories and associates his philosophical argument with one particular theory taken from economics. In contrast, Bhaskar, Collier and others make more exaggerated theoretical and policy claims on behalf of critical realism.

In particular, if Lawson is right in his assertion that a whole range of possible theories is consistent with critical realism, then a number of important questions still remain. Among these are the following: Why do these authors choose and concentrate upon these particular examples in critical realist writings? In what sense can such an exposition 'illustrate' critical realism? And why are some particular alternative theories or explanations rejected?

Rather than attacking critical realism directly, this essay focuses on the four claims (a), (b), (c) and (d), as well as the questions that are raised in the preceding paragraph. A crucial part of the argument here is to show that alternative theories, rejected respectively by Collier and Lawson, are also consistent with critical realism. In particular, contrary to the arguments of Collier and Lawson, it is argued that an (untenable) 'law of the tendency of the rate of profit to rise' (implicitly countered by Collier) and the (plausible) 'management failure thesis' (explicitly rejected by Lawson) are both consistent with critical realism, when suitably formulated.

While no overall verdict is pronounced here on critical realism as a philosophical approach, these case studies provide some insights concerning critical realism as a 'movement' or 'project'. Accordingly, after looking at the two case studies, some observations are made in the concluding section concerning the character of critical realism, especially as it is presented to academic economists. 


\section{Does critical realism support Marx's theory of the falling rate of profit? Or could a theory of a rising rate of profit be consistent with critical realism?}

In a book on critical realism, Collier (1989, pp. 66-7) refers to the debate on the validity of Marx's 'law of the tendency of the rate of profit to fall' as an illustration of his philosophical approach. As I am the main person singled out for criticism by Collier I have a special interest in raising it. According to Collier, my arguments against this alleged Marxist 'law' are wrong, and inconsistent with critical realism. I claim the contrary, on both counts.

In chapters 13-15 in the third volume of Capital, Marx (1981) attempted to show that there is a tendency, rooted in the structures of the capitalist mode of production, for the rate of profit to fall. Marx defined the general rate of profit as the total amount of profit (or 'surplus value') divided by the total value of the fixed and circulating capital advanced by the capitalists. ${ }^{3}$ The general rate of profit is the rate of return on investment for the capitalist class as a whole. Marx argued that capitalism has a tendency, as capital accumulates and technical progress advances, to substitute machinery for labour. In other words, production becomes more machine-intensive. In turn, Marx assumed that this results in a tendency for the value of capital goods (or 'constant capital') per worker-hour to increase. He argued that the denominator in the expression for the general rate of profit would tend to increase more rapidly than the numerator. According to Marx, there is a consequent underlying tendency for the general rate of profit to fall within capitalism.

Marx clearly believed that this tendency would eventually be manifest empirically. Marx (1981, p. 337) wrote: 'In practice, the rate of profit will fall in the long run’. It was not simply an 'underlying tendency' that never surfaced in the actual world. For Marx, in critical realist terminology, the law ultimately operated at the 'empirical' and 'actual' levels, and not simply the 'real'. (Of course, for critical realists, the 'empirical' and 'actual' are also 'real'.) However, Marx was rightly aware that any economic 'law' is a propensity, rooted in economic structures, rather than a sequence of empirical events.

Having made this argument, Marx (1981, pp. 339-48) then went on to discuss some 'counteracting factors' or 'counteracting influences' that would supposedly delay or ameliorate any fall in the rate of profit. One of these is the 'cheapening of the elements of constant capital'. Alongside a supposed tendency of capitalism to increase the physical quantity or complexity of machinery per worker, Marx also recognised the tendency for the 
physical quantity of output per worker to increase. In other words, by some appropriate measure, labour productivity has a tendency to increase.

As a result of these productivity increases, the (monetary) value of (or socially necessary labour time embodied in) each physical unit of capital goods would decrease. Consequently, this 'cheapening of the elements of constant capital' means that the physical mass of capital goods per worker might increase but this may not necessarily result in an increase in the (monetary or labour) value of that constant capital. As Marx (1981, p. 343) himself put it: 'In certain cases, the mass of the constant capital elements may increase while their total value remains the same or even falls.'

In other words, the denominator of the expression of the rate of profit may not increase, and the 'counteracting factors' may nullify a fall in the rate of profit. Marx believed that the 'counteracting factors' might be sufficiently strong to keep up, or even increase, the rate of profit for a while. Nevertheless, he wrote, 'the rate of profit will fall in the long run'. Marx discusses the interaction between the 'the law of the tendency of the rate of profit to fall' and the labelled 'counteracting factors' at length. Sometimes he considers cases where the 'counteracting factors' hold sway. But he still proclaims profit falls and crises as the outcome and last word (Marx, 1981, p. 375).

To draw his conclusion, Marx had to assume that the 'tendency of the rate of profit to fall' eventually dominates the 'counteracting factors'. Critical realists might interpret Marx as saying that the 'tendency' has some kind of eventual causal dominance over the 'counteracting factors'.

Marx’s supposed 'law' has been criticised by a number of authors (Sweezy, 1942; Okishio, 1961; Hodgson, 1974; Steedman, 1977; Van Parijs, 1980, Bowles, 1981). There are several key arguments against the law. One of the principal counter-arguments is quite simple: there is no reason given by Marx why the 'tendency of the rate of profit to fall' will eventually win out over the 'counteracting factors'. There is no reason why one has causal priority, is more fundamental than, or dominates the other.

In addition, the tendency of capitalism to increase labour productivity is also likely to cheapen the elements of constant capital. This cheapening of capital goods may overwhelm the forces acting on the rate of profit in the opposite direction, and the rate of profit may thus rise. There are forces acting in both directions, and we have no reason to assume that the 
downward acting forces will have a tendency to win out over those acting in the opposite direction. There is no basis to claim a principal tendency for the rate of profit to fall, or a principal tendency for it to rise.

After the brief post-1968 revival of Marxism, the debate over Marx’s law reached a peak in the 1970s. Subsequently, the debate subsided after the supporters of the law failed to refute the counter-arguments. The defenders of the law failed to provide a single reason why there should be a tendency - manifest empirically or otherwise - for the denominator in the rate of profit equation to increase faster than the numerator. They failed to provide a single argument to show why the alleged principal 'tendency', depending on a sufficiently rapid increase in the value of the capital goods per worker, was more fundamental or important than the alleged 'counteracting factors', including the cheapening of those capital goods. Accordingly, Philippe Van Parijs's (1980) careful and intelligent summary of the debate was appropriately entitled 'an obituary' for Marx’s law. ${ }^{4}$

Some years later, Collier (1989) enters the fray, bringing critical realism into the dispute. Strangely, he does not identify any of the critical works against Marx's law that are cited above. Remarkably, he chooses just one critic as an adversary - myself. But he does not cite my 1974 article, which is my only work devoted entirely to criticism of Marx's law. Instead, he addresses a later article of mine (Hodgson, 1982a) that does not enter into detailed discussion over the law, to concern itself instead with other issues. In other words, among a host of works critical of Marx's law, the work chosen as the object of Collier's critical realist counter-attack, is a single article that is not even principally devoted to criticising that law.

Collier (1989, p. 67) rightly argues that 'there is a multitude of generative mechanisms at work' and says quite reasonably that 'science must necessarily abstract from some of them to formulate laws, while remembering that the concrete situation is always a conjuncture ... of several interacting processes.' Fair enough. But that does not give us a law of the rate of profit to fall any more than it gives us a law of the rate of profit to rise.

Collier seems to think that simply by mentioning the magic concept of abstraction that he has clinched the matter. But there is no justification to simply jump from the statement that there are 'several interacting processes' and the outcome 'is multiply determined' to the statement that 'there is a mechanism in capitalism which necessarily generates a tendency of the rate of profit to fall' (Collier, 1989, p. 68). What Collier seems to be arguing - although it 
is far from clear - is that the economist must (for some unspecified reason) focus on the forces acting in a downward direction, leaving the upward-acting forces out of vision, so as to derive 'the law of the tendency of the rate of profit to fall.'

But the use of the concept of abstraction cuts both ways. In contrast to Collier, one could choose to focus on the tendency of capitalism to increase labour productivity and to thereby cheapen the elements of constant capital, thus 'abstracting from' the forces with an opposite result on the rate of profit. In this case, to use another useful critical realist phrase, increasing labour productivity in the production of capital goods is the 'generative mechanism' upon which I choose to focus. Neither Marx nor Collier gives any reason why these forces, which tend to cheapen the value of capital goods, should be regarded as less deeply rooted in the structures of capitalism. Neither Marx nor Collier gives any reason why one set of tendencies results from a 'generative mechanism' and the other does not. Marx focuses arbitrarily on one set, abstracting from the other. My alternative 'abstraction' in this paragraph is equally arbitrary. I here describe the tendency to cheapen constant capital as resulting from the 'generative mechanisms' of increasing productivity, and 'abstract from' those forces tending to bring down the rate of profit.

Hey presto! According to the same critical realist methodology, I formulate 'the law of the tendency of the rate of profit to rise.' The basic structure of the 'abstraction' argument in the last two paragraphs is identical. The conclusions are equally phoney. None of them proves a 'law' that has any special status over tendencies working in the opposite direction.

It is reasonable to ask why Marx and his defenders give the downward pressing forces the description and implied status of a 'law' and those that press in the opposite direction are labelled 'counteracting factors'. It is not enough simply to describe forces pushing downwards as 'laws' or 'tendencies' and those pressing upwards as merely 'counteracting factors'. This is an arbitrary, unwarranted and misleading labelling. In an equally unjustified and arbitrary manner, the labels in Marx's theory could be switched, giving the 'cheapening of the elements of constant capital' a higher status, calling those acting to push down the rate of profit 'counteracting factors'. This would also result in 'the law of the tendency of the rate of profit to rise'. Given that Marx's labelling of one as the 'law' and the other set of forces as 'counteracting' is entirely arbitrary, by the same canon we can arbitrarily switch the labels, giving the opposite result (Hodgson, 1974, p. 76). I made this argument thirty years ago. No defender of Marx’s law has ever given an adequate reply to this argument. 
To show why 'there is a mechanism in capitalism which necessarily generates a tendency of the rate of profit to fall', Collier needs to show why the 'downward' set of forces dominates the forces acting in the reverse direction. Only then will the choice of 'abstraction' cease to be arbitrary. But no text from critical realism gives any guidance on this particular question. To use the language of critical realism: we have two sets of 'generative mechanisms' or forces. There are 'generative mechanisms' acting to push down the rate of profit. In addition, there are 'generative mechanisms' - resulting from a tendency within capitalism for labour productivity to increase - acting to push up the rate of profit. Concerning the rate of profit, why give one set of 'generative mechanisms', any higher (or lower) ontological, law-like or explanatory status than the other? Critical realism has not yet provided an adequate methodology to help us to find an answer.

But I hear a possible critical realist response to this - the sound of falling leaves. It might be argued that the law of gravity acts to make the leaf fall, but this outcome might be suspended or countered by wind wafting it upwards. However, falling leaves are not the same things as falling profits, and they involve different types of causal mechanism. In particular, in the physical world, gravity and the wind are not the same kind of causal mechanism and they operate on different ontological levels. Wind is an emergent property of a huge pack of gas particles, whereas gravity applies to every single particle in the universe. In this sense, the law of gravity acting on a leaf is more fundamental than the wind wafting it upwards. This is because the forces of gravity, while varying, are always present whenever two or more masses are in proximity. On the contrary, a wind depends on the existence of an atmosphere and the direct collusion of the atmospheric particles with the object. Accordingly, physics has developed a theory of the motion of a body in a vacuum, prior to amending it to include any contingent atmospheric forces.

In contrast, in the economic domain, there is no basis whatsoever to give those forces that would lead to a fall in the rate of profit any higher law-like, causal or explanatory status than the increases in the productivity of capital goods that tend to increase the profit rate. Critical realism does not tell us which has priority over the other. Its method of abstraction can lead just as much to 'the law of the tendency of the rate of profit to rise.' Critical realism does not support the 'law of the tendency of the rate of profit to fall' neither does it show that the criticisms of the law are invalid. 
The error in Collier's account is to jump from the valid proposition that tendencies are not always realised at the level of events to the arbitrary choice of a tendency that he sees as the important one. He fails to show that other countervailing tendencies - whether or not realised at the level of events - are unimportant. The ontology of tendencies does not give us licence to choose some tendencies and ignore others. But Collier, following Marx, gives just one tendency unwarranted law-like status.

There is a finale to all this. Immediately following his attempted rebuttal of my criticisms, and in concluding his discussion of the falling rate of profit, Collier writes: 'nor does it mean that that we can't forecast with some degree of confidence that capitalism will collapse'. This is a curious and symptomatic double negative. It seems that Collier would like to assert that we can forecast with some degree of confidence that capitalism will collapse. When critics, such as myself, point out that we are unable to predict the actual tendency of the rate of profit we are then lectured about scientific method. We are told that we should ignore empirical manifestations and focus on the deeper 'generative mechanisms'. In contrast, Collier himself is seemingly allowed to move to the empirical level and invite a 'forecast with some degree of confidence that capitalism will collapse' without giving any valid reason for such a forecast.

Collier is wrong about 'the law of the tendency of the rate of profit to fall'. And critical realism, per se, gives us valid arguments neither for nor against this alleged 'law'. At the crucial point, in deciding which set of forces might have priority over the others, it gives us no guidance. Additional arguments would be required, extraneous to critical realism, at least as we know it so far. In sum, contrary to Collier, critical realism offers no support to Marx's theory on this question.

\section{Is critical realism illustrated by the workplace organisation theory of the relative decline of the British economy? And does critical realism lead to a rejection of the management failure thesis?}

In his Economics and Reality, Lawson (1997) presents a major statement on critical realism and on its significance for economics. In an era when many economists have lost their way in mathematical puzzles, forgetting that their science should be principally concerned to understand and explain economic phenomena in the real world, Lawson's book comes as salutary reading. But it is not my concern here to assess this volume overall. What I am 
concerned to do is to look at the implications of the approach that Lawson attempts to develop for the practice of economic science. Apart from making a case against mathematical formalism in economics, Lawson makes some illustrated claims concerning the application of critical realism as an adjudicator in theoretical disputes.

However, there are several remarkable omissions from his discussion of the possible implications of critical realism. There is no consideration, for example, of different theories of price or value, of monetarism versus Keynesianism, of the causes of economic growth, or of many of the prominent theoretical questions that have concerned economists in recent decades. To move beyond criticism of the mainstream to the construction of an alternative, we are left asking how critical realism may, more specifically, guide the choice or construction of economic theory.

I sympathise with Lawson, because he is in a difficult position here. As I know from my own attempts to criticise mainstream economics, the response is typically: 'What, then, are the implications of your approach? What do you propose instead?' The critic is then seemingly faced with the impossible task of rebuilding economic theory single-handed. In practice, the most that can reasonably be expected is a few illustrations of the implications of the proposed alternative approach.

When Lawson turns to such illustrations in his book, he chooses just one application of critical realism to a substantive theoretical controversy in economics. This is the debate concerning the causes of the long-term relative decline of the British economy. Lawson's choice of this example is understandable: some time ago he himself made a major contribution to this debate. But it may be unwise to stake all on just one (challengeable) illustration.

In one of the major formulations of the workplace organisation thesis, Andrew Kilpatrick and Tony Lawson (1980) argue that worker resistance to technological and workplace change in Britain, based largely on the strength of trade union organisation and the decentralised nature of collective bargaining, contributed substantially and cumulatively to Britain's loss of its world lead in several of its manufacturing sectors. There is much evidence in support of this argument and it has considerable plausibility. Similar or related arguments have been put forward by Andrew Glyn and Robert Sutcliffe (1972), David Purdy (1976) and G. Bernard Stafford (1983), among others. In his 1997 book, Lawson argues that this account is rooted in 
the social structures of work organisation and conforms to the explanatory requirements of critical realism. His claim is that the workplace organisation thesis is an 'illustration' of critical realism because it is an 'empirically grounded' explanation of a social phenomenon that is 'couched in terms of structures and mechanisms that are reproduced overtime, where that reproduction is itself explained' (Lawson, 1997, p. 247).

The first problem is that there are several competing explanations of Britain's relative industrial decline. Some theories may be rejected on the grounds that they are implausible, misconceived, denied by the evidence, or internally logically inconsistent. Some of the remaining multiple explanations may be mutually incompatible. In which case some further explanations have to be rejected, on the basis of their false assumptions or whatever. But, after these processes of filtering, we still may be left with a substantial number of plausible theories. The remaining set will contain theories which are potentially complementary, leading to possibility of multiple and logically compatible explanations of a single complex phenomenon (Mäki, 1997).

Consider some prominent alternative explanations of the British relative decline. Studies have pointed to low investment and productivity in manufacturing (Kaldor, 1966), the institutional schism between the City and industry (Hobsbawm, 1968; Ingham, 1984), the low skill levels in British management (Caves, 1980; Landes, 1969; Wiener, 1981; Wilson, 1995), or the sclerotic nature of British economic and political institutions (Choi, 1983; Elbaum and Lazonick, 1986; Hodgson, 1989, 1996).

In assessing these different explanations, we may ask, first of all, is a plausible causal explanation offered? Even if the answer is in the affirmative, the problems of theory choice do not end there. We may end up with several viable causal explanations. We may not be able to exclude any more of them. They may be mutually compatible. We may reach the conclusion that the remaining explanations may all be causally operative. The problem, then, is how do we decide among them: which are the more important? We have a number of causal arrows. The problem is to determine which are the strongest and thickest in the circumstances.

This problem of comparative causal assessment among potentially compatible theories is ubiquitous in economics. Take the problem of unemployment as an example. Collier (1994, p. 171) rightly rejects the 'fecklessness' theory of unemployment. However, some people may in fact be unemployed because they are feckless. We may be able to discover some unemployed 
people who are too lazy to get a job - that being a major reason for their idleness. But this does not mean that the fecklessness theory of unemployment is generally correct. The theory remains generally invalid partly because it points only to a very minor causal arrow. Some unemployment is caused by fecklessness, but the fecklessness theory is wrong as the principal explanation of unemployment. It fails to explain the sudden increases in unemployment in recessions and the durability and scale of this mass phenomenon. We do not refute the fecklessness theory of unemployment because it fails to identify any causal link. We refute it because the causal link is of relatively little significance.

A similar problem arises, for example, in the debate between monetarist and rival theories of inflation. I am not aware of any economist who has denied that an expansion in the money supply can have inflationary consequences. No one has denied the possibility of a causal link between the supply of money and the price level. Instead, the debate between monetarists and Keynesians is over whether the money supply is, or is not, the most important causal mechanism involved in forcing up prices.

In an important paper, Jochen Runde (1998) discusses the problem of assessing causal explanations from a critical realist perspective. Notably, and judiciously, he does not claim too much. From a realist viewpoint, Runde is clearly able to dismiss causal explanations that depend upon unreal idealisations 'that have no existence other than in the minds and discourse of scientific investigators' (p. 159). He further argues that candidate factors should be 'causally effective', be 'sufficient' and have 'causal depth'. These are important arguments, but they do not take us as far as some may wish. Runde admits that the 'the prospects for a universal method of assessing causal explanations are ... poor' (p. 165) and the 'principles used to assess causal explanations ... will often not have sufficient bite, to discriminate unambiguously between competing causal explanations. ... there will always be situations in which it is not possible to identify one explanation as unambiguously superior to its rivals' (p. 168). His paper does not show that critical realism has very much more to add here. This is not necessarily devastating for critical realism, but it should encourage some much needed modesty from some other critical realists on what can be claimed for their philosophy.

Critical realism rightly emphasises the importance of causal mechanisms, but it gives us little guidance to assess the importance of one causal link compared with another. It emphasises underlying social structures, but even this does not clearly indicate what is more 
important or fundamental. It can be argued that this is not the task of critical realism: philosophy cannot legislate for science. If so, then in what sense is Lawson's single chosen example of a causal explanation of Britain's relative industrial decline an 'illustration' of critical realism? The meaning and very possibility of such an illustration is called into question.

Let us return to the assessment of the specific causes of Britain's relative industrial decline. Lawson (1997, p. 256) makes the claim that:

The most comprehensive attempt, that I am aware of, to compare the explanatory powers of the range of theories, has been carried out by Stafford (1983). This author deduces implications which would follow if the different theories considered were true, and checks each out empirically in the appropriate context. On the basis of a wealth of detailed evidence ... this author concludes in favour of an explanation which attributes at least part of the responsibility for the experience of relatively slow growth in the UK to the ... far more highly decentralised system of collective bargaining compared to that which emerged elsewhere, along with the associated relatively localised nature of worker organisation in the UK.

At first sight this seems an attempt to answer the problem of comparative causal assessment. Lawson cites Stafford, who does in fact give some explanatory precedence to the workplace organisation thesis. ${ }^{5}$

But note Lawson's precise claim here. After comparing the explanatory powers of different theories, and on the basis of an alleged 'wealth of detailed evidence' Stafford is said to conclude 'in favour of an explanation which attributes at least part of the responsibility' (emphasis added) to the relatively decentralised nature of collective bargaining and relatively localised worker organisation in the UK. ${ }^{6}$ However, saying that we have identified a cause that is partly responsible for a phenomenon is not saying that we have identified the most important cause of the phenomenon. We cannot yet exclude the possibility that other factors were more important in causing the relatively slow growth of the British economy. It is necessary to deal with the crucial problem of comparative causal assessment among competing and potentially compatible theories. This is especially the case if we wish to draw policy conclusions. 
Consequently, Lawson does not exclude other explanations from being part of the picture. In fact, he is ambivalent about this. In passages in Economics and Reality he clearly argues that the process of abstraction is a deliberately selective view, 'meaning looking at something in a "one-sided” manner' (Lawson, 1997, p. 236). But Lawson also insists that this gives us no licence to assume that other causal mechanisms are non-existent: 'there is literally a world of difference between leaving something (temporally) out of focus and treating it as though it does not exist' (ibid.). However, in his account of the British industrial decline, and without adequate reason, he steers us (permanently) towards one view only.

Lawson attempts to steer this way on methodological grounds. He argues that the 'structure' of British work organisation empowered worker resistance to technological change. 'In short, the explanation in question focuses on a set of structures that empowers workers (as well as others) to exercise a significant effect on all manner of outcomes' (Lawson, 1997, p. 257). Having emphasised structure, he then tries to exclude some other explanations. Hence he writes: a 'social explanation which ignores the social reproduction of causally efficacious structures will often be too partial to constitute an adequate or sufficiently comprehensive understanding' (p. 268). However, while this persuasive methodological injunction would find some explanations inadequate, the workplace organisation thesis does not have exclusive title to conform to it. The truth is that several alternative theories would pass Lawson's methodological test.

Lawson admits the possibility of alternative or complementary explanations, but still does his best to raise the workplace organisation thesis to the highest profile. The manner in which this is done is partly by exclusion. A host of alternative explanations, including Geoffrey Ingham's (1984) refined study of the role of the City, and my own focus on institutional rigidities (Hodgson, 1989) are simply omitted from Economics and Reality. Of course, it would be impossible to mention all possible rival theories. Nevertheless, any selectivity does give the impression that the preferred theory has some special status above the rest. Otherwise, why is it selected?

The second of Lawson's tactics is to belittle other competing or more inclusive explanations, by suggesting that they fail his methodological tests. In particular, this is how the management failure thesis is addressed: 
If ... British management is really somehow less capable or more complacent ... then presumably those brought in from overseas ... should be found to be associated with productivity performances that are frequently notably better. (Lawson, 1997, p. 270)

But the conclusion does not follow from the premise. In the above passage, Lawson treats managers as if they are social atoms, who retain their individual competencies or inadequacies, as they are moved from one context to another. Even if some proponents have made this mistake, it is wrong to reduce the arguments and evidence of British management failure to matters of individual capability or complacency that derive from the individuals alone. On the contrary, a fairer treatment of the argument that British managers are less capable or more complacent would treat it on the same intellectual level as Lawson's own argument that British workers have been more militant and less accommodating to change.

To show this, let us treat workers as if they are social atoms, with unchanging capacities to resist in different contexts, and argue that: 'presumably workers brought in from overseas are more accommodating, and British workers who emigrate retain their propensity to resist'. If the above quoted passage by Lawson (1997, p. 270) is a valid objection to the management failure thesis then the last sentence is a valid objection to the workplace organisation thesis.

But, of course, neither argument is convincing. They are both very weak objections because they ignore the structural constraints and institutional determinations of managerial or worker behaviour. Lawson's rejection of the management failure thesis fails, because it ignores the structural constraints and institutional determinations of managerial behaviour. He is not consistent in his criteria of theory assessment. This particular attempt to steer the reader away from an alternative - and by default in the direction of the workplace organisation thesis fails. It may be that versions of the management failure thesis are equally 'illustrative' of critical realism. We have no reason to assume otherwise. There is no adequate comparative assessment of the two theories in Lawson's work.

Importantly, structural constraints and institutional determinations have not been omitted from several accounts of entrepreneurial or management failure in Britain. For example, in a detailed, sophisticated and multi-faceted institutional analysis, Bernard Elbaum and William Lazonick (1986) write:

We attribute the decline of the British economy in the twentieth century to rigidities in the economic and social institutions that developed during the nineteenth century ... 
Britain's problem ... was that economic decision-makers, lacking the individual or collective means to alter existing constraints, in effect took them as 'given'. In failing to confront institutional constraints innovatively, British businessmen can justifiably be accused of 'entrepreneurial failure'. But this failure cannot be adequately explained by reference to cultural conservatism, despite the frequency of such assertions. ... Britain's failure derived less from the conservatism of its cultural values per se than from a matrix of rigid institutional structures that reinforced these values and obstructed individualistic as well as collective efforts at economic renovation. (Elbaum and Lazonick, 1986, p. 2)

It is abundantly clear from this quotation that managerial or entrepreneurial failure is here seen as rooted in social and economic institutions, and contrary to Lawson's critical depiction, it is not merely a matter of the personal or psychological propensities of atomistic individuals.

In a brief and restrictive discussion of some of the alternative theories, Lawson (1997, p. 269) admits: 'To the extent that such claims can be supported empirically and are complementary to the sort of explanation identified here there is no problem'. But again he gives little guidance as to the way in which we may assess the relative importance of each causal mechanism involved. The nearest we get to an answer to this crucial question is right at the end of the relevant chapter, where he writes of 'relative empirical grounding' as a basis of comparative theory assessment. A theory would be supported if it 'is found to be the most empirically adequate' (Lawson, 1997, p. 270). But the precise test of empirical adequacy is not made clear. These words by themselves are extremely inadequate, and do nothing to exclude a whole host of rival explanations of Britain's relative economic decline. Above all, Lawson's account of critical realism in economics does not show us how to engage in the crucial task of comparative causal assessment. As yet, critical realism is far from grounding and demonstrating the particular theoretical conclusions that it uses as exemplars, or to which it declares allegiance.

I am not taking sides here in the dispute over the different causes of the British relative economic decline. The point of this argument has not been to resolve this debate but to show that critical realism does not especially countenance the particular explanation favoured by Lawson. In particular, Lawson's attempt to exclude the important 'management failure thesis', using critical realist tools, fails. Contrary to Lawson, there is nothing that is essential to the 'management failure thesis' that inconsistent with critical realism. 
Critical realism is possibly useful in helping to exclude some explanations, particularly those with inadequate causal explanations. But as so far constructed it leaves us, not only with a substantial set of remaining and contrasting theories, but also without adequate means to discriminate between them, on explanatory or empirical terms. Lawson's attempt to use critical realism to discriminate between the 'management failure thesis' and his own preferred theory is a failure.

It is not that critical realism has been shown to be wrong here. It is simply that it is in danger of claiming too much by stressing and focussing upon one explanation. As Lawson (1997, p. 268) himself admits, he has been too 'partial' on this question. Lawson wavers between presenting the workplace organisation thesis as one explanation among many, and presenting the thesis as a front runner by ignoring or attempting to reject other theories. In fact, critical realism gives us no reason to exclude or belittle alternative explanations. Critical realism has not shown that alternative theories - such as managerial failure, or institutional sclerosis - are less plausible or powerful. As yet, critical realism has not led us to any particular explanation of Britain's industrial decline. Furthermore, it has not shown us how to assess the relative causal weights of several plausible and possibly complementary theories. As Lawson (1997, pp. 270-1) himself admits, the task is not yet done.

The contentious claim is that the workplace organisation thesis is somehow an 'illustration' here of critical realism. But the point here is that critical realism could just as well be illustrated by other explanations, including some that Lawson chooses to ignore or reject. My argument here is not that the chosen theory is right or wrong, but that after some suitably critical realist tests, critical realism is consistent with a variety of rival explanations of the British decline, and gives us inadequate guidance to choose one 'illustration' over another. As a result, Lawson's notion of an 'illustration' of critical realism itself becomes severely weakened.

\section{Concluding remarks}

We have examined two case studies of critical realism and their claimed implications or illustrations for economics. Here are the results: 
A1. It is claimed that critical realism supports Marx's 'law of the tendency of the rate of profit to fall'. However, this claim is not based on an assessment of the appropriate critical literature and powerful key arguments against Marx’s law are not addressed.

A2. In particular, using the same critical realist arguments and terminology, it is possible to formulate an (equally dubious) 'law of the tendency of the rate of profit to rise'. Consequently, critical realism is compatible with both Marx's law and its opposite.

B1. It is claimed that critical realism is 'illustrated' by the workplace organisation explanation of the relative decline of the British economy. Lawson's version of the workplace organisation thesis passes a critical realist test: it points to underlying structures and causal mechanisms.

B2. The problem is that a substantial number of other theories would also seem to pass the test, and critical realism provides no good reason for excluding them. Above all, critical realism, as so far formulated, fails at the crucial point of comparative causal assessment of rival and potentially complementary theories.

B3. In particular, Lawson argues against the 'management failure thesis'. However, this alternative theory, when properly formulated, is also consistent with critical realism. Consequently, critical realism is compatible with at least two theories, including one that is rejected by Lawson.

C. Consequently, considering both case studies, critical realism has not yet developed adequate criteria to distinguish between rival or alternative explanations, at least in two areas of study chosen by its exponents.

Emphatically, it does not follow from the above propositions that critical realism is unfruitful or has to be rejected. The evaluation of critical realism as a philosophy has to be the task of another work. The point of this paper is not to challenge critical realism as such, but to criticise some claims that are allegedly based upon it. Consequently, leading and other critical realists (including Bhaskar, Collier and Lawson) should be more careful in making explanatory, normative or illustrative claims on behalf of their philosophy. Whether or not critical realism is a sound and useful approach, exaggerated claims on its behalf will not help its advancement in the scholarly community. Furthermore, if explanatory or other stronger claims are to be made for critical realism, then more attention has to be made to developing the criteria for comparative assessment of theories or policies. As a scholarly approach, 
critical realism would not be weakened if critical realists were much more cautious about their claims of theoretical or policy implications.

At the methodological level, critical realism succeeds in being able to criticise and exclude some theories, on the grounds that they do not point to viable causal mechanisms. According to critical realism, adequate explanations must address 'the social reproduction of causally efficacious structures' (Lawson, 1997, p. 268). But as Lawson himself notes, this does not lead us to a single theory. We still have a whole host of viable theories from which to choose. But to go further, at least one theory is mistakenly rejected by Lawson by a misapplication of the critical realist criteria that he invokes. In addition, in a number of respects, including the key question of relative causal importance, critical realism gives us no adequate means of discrimination between a number of different and plausible theories. Consequently, the claimed theoretical 'illustration' of critical realism is somewhat limited in its impact.

Critical realists make much of the concept of abstraction. But the two examples discussed here show that the question of abstraction is problematic. I am not arguing against the value of abstraction. On the contrary, it is a necessary feature of all science. The problem is that critical realism gives no clear and adequate guideline concerning what abstractions are appropriate. For example, it has been shown above that the criteria provided by Collier for abstracting the more powerful tendencies causing the rate of profit to rise, could equally well apply to those causing it to fall. Similarly, Lawson focuses on the workplace organisation theory of the British economic decline, but gives no adequate reason for downplaying several other causal mechanisms and explanations. The upshot of the two case studies discussed above is that critical realism does not as yet provide enough guidance on the question of abstraction to overcome these more concrete difficulties.

But I wish to raise another question here. Collier's adherence to Marxism as well as to critical realism is obvious from his writings. It is also perhaps no accident that the single theory that Lawson chose to 'illustrate' critical realism is one prominently described as a 'Marxist view' in a reprint of the Kilpatrick-Lawson paper (Coates and Hillard, 1986, pp. 223 ff.). The workplace organisation thesis found favour among many Marxists because it suggested two stark political alternatives: either to smash the organised resistance of the working class and restore capitalism to greater profitability, or to support a socialist worker's revolution. In their dislike of reformist compromises, Marxists have a preference for such stark choices. But the reasoning behind them does not always stand up to critical examination. 
This failure to choose additional 'illustrations', outside the orbit of what is widely (and rightly or wrongly) described as 'Marxist' is symptomatic of something else going on within critical realism. It is notable, that prominent theoretical claims and 'illustrations' of critical realism are generally of a Marxist character, even if not all critical realists are declared Marxists. To this we may add the statements of Bhaskar and Collier, cited above, which associate critical realism with some form of socialism and with a rejection 'of contemporary social democracy'. The socialist and Marxist overtones of much (but not all) critical realist writing are blatant.

Critical realism, at least as so far developed, does not support such stances. But also, given these symptoms, it is also appropriate to examine their causal origin. It would be appropriate to apply some of the canons of critical realism to the critical realist 'movement' itself. The 'sociology’ of critical realism as a movement is a suitable topic for study.

As an early step in this direction, some evidence is unearthed here that critical realism is much more than a philosophical doctrine. It seems also to be a predominantly leftist political movement, of distinctly - but not entirely - Marxist hue. I have provided further evidence and developed this claim elsewhere (Hodgson, 1999). For example, it is noticeable that when some critical realists argue that there is something of value in the works of Friedrich Hayek (Lawson, 1994; Fleetwood, 1995), they do not discuss Hayek's powerful argument that comprehensive central planning is impossible. Perhaps, for leftists, this would be too close for comfort. For many, the attraction of critical realism is that it appears to combine a radical leftist policy stance with apparent philosophical sophistication. But it is possible that, for some, the leftism rather than the philosophy is providing much of the attraction.

These concluding remarks point to questions, rather than providing answers. But in showing that critical realism is compatible with several different and sometimes contradictory positions, while in the name of critical realism some positions are promoted rather than others, these questions are surely placed on the agenda. 


\section{Notes}

${ }^{1}$ The author is very grateful to Markus Becker, Richard Carter, Wilfred Dolfsma, Steven Fleetwood, Edward Fullbrook, Clive Lawson, Tony Lawson, Uskali Mäki, Stephen Nash, Stephen Pratten, Jochen Runde, Colin Shaper, anonymous referees and many others for critical and helpful comments.

2 The modern ‘critical realism' of Bhaskar, Archer, Lawson, Collier and others should not be confused with the earlier but contrasting tradition in American philosophy describing itself as ‘critical realism’. See Sellars (1908, 1916), Bode (1922) and Moore (1922).

${ }^{3}$ The reader may choose whether 'value' is defined in terms of money or in terms of 'socially necessary embodied labour time', and whether or not they are equivalent. To resolve this question would raise the controversial issue of the labour theory of value, which in fact we do not need to discuss here. Although I am a critic of this theory (Hodgson, 1982b), the reader may prefer to assume that the labour theory of value is valid. Alternatively, the reader may wish to assume otherwise. For the purpose of this article, and this discussion of the falling rate of profit, nothing of immediate importance hinges on this question.

${ }^{4}$ See also Blaug (1980, pp. 43-7; 1997, pp. 235-40) for incisive summaries of the debates over Marx’s law.

${ }^{5}$ Lawson's over-dependence on the important but now outdated study by Stafford (1983) tempts him to exaggerate slightly. Stafford does not compare all major theories of the British decline. Stafford skips over the management failure thesis and is chronologically unable to deal with Ingham's (1984) sophisticated study of the role of City in the British decline, or with the institutionalist approach of Elbaum and Lazonick (1986). Yet, fourteen pages later, Lawson (1997, p. 270) is again found overstating the case when he refers to Stafford 'as an example where competing hypothesis of Britain's relative productivity performance have already been assessed according to their relative empirical grounding.' On the contrary, Stafford's early and preliminary assessment of the empirical evidence hardly closes the issue. After all, Stafford's single table of figures and his citation of a few historical studies is hardly 'a wealth of detailed evidence'. Stafford (1983, p. 17) himself says that the 'evidence is 
certainly not abundant'. There are more detailed data in Caves (1980, p. 173) who found 'strong statistical evidence to support the negative influence on industrial productivity of both poor labor-management relations and deficiencies in British management'. For more recent evidence on managerial failure in the UK see Grinyer et al (1998) and Sisson and Marginson (1996).

${ }^{6}$ Other than 'part of the responsibility', the only other possible meaning here of 'at least part of the responsibility' is 'all the responsibility'. Does Lawson wish to imply that there is just one cause of the relative decline of the UK? If not, then the phrase 'at least' is redundant here. 


\section{References}

Baert, Patrick (1996) 'Realist Philosophy of the Social Sciences and Economics: A Critique', Cambridge Journal of Economics, 20(5), September, pp. 513-22.

Bhaskar, Roy (1975) A Realist Theory of Science, $1^{\text {st }}$ edn. (Leeds: Leeds Books).

Bhaskar, Roy (1989) Reclaiming Reality: A Critical Introduction to Contemporary Philosophy (London: Verso).

Bhaskar, Roy (1991) Philosophy and the Idea of Freedom (Oxford: Basil Blackwell).

Bhaskar, Roy (1993) Dialectic: The Pulse of Freedom (London: Verso).

Bhaskar, Roy and Collier, Andrew (1998) 'Introduction: Explanatory Critiques', in Archer, Margaret S., Bhaskar, Roy, Collier, Andrew, Lawson, Tony and Norrie, Alan (eds) (1998) Critical Realism: Essential Readings (London: Routledge), pp. 385-94.

Blaug, Mark (1980) A Methodological Appraisal of Marxian Economics (Amsterdam: NorthHolland).

Blaug, Mark (1997) Economic Theory in Retrospect, 5th edn. (Cambridge: Cambridge University Press).

Bode, B. H. (1922) ‘Critical Realism’, Journal of Philosophy, 19(3), February, pp. 68-78.

Bowles, Samuel (1981) 'Technical Change and the Profit Rate: A Simple Proof of the Okishio Theorem', Cambridge Journal of Economics, 5(2), June, pp. 183-6.

Caves, Richard E. (1980) 'Productivity Differences Among Industries', in Caves, Richard E. and Krause, Lawrence B. (eds) (1980) Britain's Economic Performance (Washington, DC: Brookings Institution), pp. 135-98.

Choi, Kwang (1983) 'A Statistical Test of Olson’s Model’, in Mueller, Dennis C. (ed.) (1983) The Political Economy of Growth (New Haven: Yale University Press), pp. 57-78.

Coates, David and Hillard, John (eds) (1986) The Economic Decline of Modern Britain: The Debate Between Left and Right (Brighton: Harvester).

Collier, Andrew (1989) Scientific Realism and Socialist Thought (Hemel Hempstead: Harvester Wheatsheaf). 
Collier, Andrew (1994) Critical Realism: An Introduction to Roy Bhaskar's Philosophy (London: Verso).

Downward, Paul (2000) ‘A Realist Appraisal of Post-Keynesian Pricing Theory’, Cambridge Journal of Economics, 24(2), March, pp. 211-24.

Elbaum, Bernard and Lazonick, William (eds) (1986) The Decline of the British Economy (Oxford: Oxford University Press).

Fleetwood, Steven (1995) Hayek's Political Economy: The Socio-Economics of Order (London: Routledge).

Fleetwood, Steven (ed.) (1998) Critical Realism in Economics: Development and Debate (London: Routledge).

Faulkner, Philip (2002) 'Some Problems With the Conception of the Human Subject in Critical Realism', Cambridge Journal of Economics, 26(6), November, pp. 739-51.

Glyn, Andrew and Sutcliffe, Robert (1972) British Capitalism, Workers and the Profits Squeeze (Harmondsworth: Penguin).

Grinyer, J., Russell, A. and Collison, D. (1998) 'Evidence of Managerial Short-Termism in the UK', British Journal of Management, 9(1), pp. 13-22.

Hobsbawm, Eric J. (1968) Industry and Empire (London: Weidenfeld and Nicolson).

Hodgson, Geoffrey M. (1974) 'The Theory of the Falling Rate of Profit', New Left Review, no. 84, March/April, pp. 55-82. Reprinted in Hodgson (1991).

Hodgson, Geoffrey M. (1982a) 'On the Political Economy of the Socialist Transformation', New Left Review, no. 133, May/June, pp. 52-66.

Hodgson, Geoffrey M. (1982b) Capitalism, Value and Exploitation: A Radical Theory (Oxford: Martin Robertson).

Hodgson, Geoffrey M. (1989) 'Institutional Rigidities and Economic Growth’, Cambridge Journal of Economics, 13(1), March, pp. 79-101. Reprinted in Lawson, Tony, Palma, J. Gabriel and Sender, John (eds) (1989) Kaldor's Political Economy (London: Academic Press) and Hodgson (1991).

Hodgson, Geoffrey M. (1991) After Marx and Sraffa: Essays in Political Economy (London: Macmillan). 
Hodgson, Geoffrey M. (1996) 'An Evolutionary Theory of Long-Term Economic Growth’, International Studies Quarterly, 40, pp. 393-412.

Hodgson, Geoffrey M. (1999) 'Marching to the Promised Land?: Some Doubts on the Theoretical and Policy Affinities of Critical Realism’ with a response by Andrew Collier and a rejoinder, Alethia, 2(2), October, pp. 2-13.

Ingham, Geoffrey (1984) Capitalism Divided? The City and Industry in British Social Development (London: Macmillan).

Kaldor, Nicholas (1966) Causes of the Slow Rate of Economic Growth in the United Kingdom: An Inaugural Lecture (Cambridge: Cambridge University Press). Reprinted in Kaldor, Nicholas (1978) Further Essays on Economic Theory: (Collected Economic Essays Vol. 5) (London: Duckworth).

Kilpatrick, Andrew and Lawson, Tony (1980) 'On the Nature of the Industrial Decline in the UK', Cambridge Journal of Economics, 4(1), March, pp. 85-102.

Landes, David S. (1969) The Unbound Prometheus (Cambridge: Cambridge University Press).

Lawson, Tony (1994) 'Hayek and Realism: A Case of Continuous Transformation', in Colonna, Marina, Hagemann, Harald and Hamouda, Omar F. (eds) (1994) Capitalism, Socialism and Knowledge: The Economics of F. A. Hayek, Volume 2 (Aldershot: Edward Elgar), pp. 131-59.

Lawson, Tony (1997) Economics and Reality (London: Routledge).

Lewis, Paul A. (1996) 'Metaphor and Critical Realism', Review of Social Economy, 54(4), Winter, pp. 487-506.

Mäki, Uskali (1997) 'The One World and Many Theories’, in Salanti, Andrea and Screpanti, Ernesto (eds) (1997) Pluralism in Economics: New Perspectives in History and Methodology (Aldershot: Edward Elgar), pp. 37-47.

Marx, Karl (1981) Capital, vol. 3, translated by David Fernbach from the German edition of 1894 (Harmondsworth: Pelican).

Moore, A. W. (1922) 'Some Logical Aspects of Critical Realism’, Journal of Philosophy, 19, October, pp. 589-96. 
Okishio, N. (1961) 'Technical Change and the Profit Rate', Kobe University Economic Review, 7, pp. 86-99.

Purdy, David L. (1976) 'British Capitalism Since the War', Parts I and II, Marxism Today, September and October.

Runde, Jochen H. (1998) 'Assessing Causal Economic Explanations', Oxford Economic Papers, 50(1), pp. 151-72.

Sellars, Roy Wood (1908) 'Critical Realism and the Time Problem', Journal of Philosophy, 5(20, 22), September, pp. 542-48 and October, pp. pp. 597-602.

Sellars, Roy Wood (1916) Critical Realism: A Study of the Nature and Conditions of Knowledge (Chicago: Rand-McNally).

Sisson, K. and Marginson, P. (1996) 'Management Systems, Structures and Strategy', in Edwards, P. K. (ed.) (1996) Industrial Relations (Oxford: Basil Blackwell), pp. 89-122.

Stafford, G. Bernard (1983) 'The Class Struggle, The Multiplier and the Alternative Economic Strategy' in Malcolm Sawyer and Kerry Schott (eds), Socialist Economic Review 1983 (London: Merlin), pp. 1-21.

Steedman, Ian (1977) Marx After Sraffa (London: NLB).

Sweezy, Paul M. (1942) The Theory of Capitalist Development (London: Dobson).

Van Parijs, Philippe (1980) 'The Falling-Rate-of-Profit Theory of Crisis: A Rational Reconstruction by Way of Obituary', Review of Radical Political Economics, 12(1), Spring, pp. 1-16.

Walters, B. and Young, David (1999) 'Is Critical Realism the Appropriate Basis for Post Keynesianism?', Journal of Post Keynesian Economics, 22(1), Fall, pp. 105-23.

Wiener, Martin J. (1981) English Culture and the Decline of the Industrial Spirit 1850-1980 (Cambridge: Cambridge University Press).

Wilson, John F. (1995) British Business History, 1720-1994 (Manchester: Manchester University Press).

Wright, Erik Olin (1994) Interrogating Inequality: Essays on Class Analysis, Socialism and Marxism (London: Verso). 
- 27 - 